\title{
Article
}

\section{Evaluation of a cognitive skills programme for male prisoners - exploring treatment effectiveness}

Ireland, Jane Louise, Bates-Gaston, J, Markey, K, Greenwood, Leah Charlotte and Ireland, Carol Ann

Available at http://clok.uclan.ac.uk/14932/

Ireland, Jane Louise ORCID: 0000-0002-5117-5930, Bates-Gaston, J, Markey, K, Greenwood, Leah Charlotte and Ireland, Carol Ann ORCID: 0000-0001-73102903 (2016) Evaluation of a cognitive skills programme for male prisoners exploring treatment effectiveness. Journal of Criminological Research, Policy and Practice, 2 (4). pp. 244-249. ISSN 2056-3841

It is advisable to refer to the publisher's version if you intend to cite from the work. http://dx.doi.org/10.1108/JCRPP-06-2016-0011

For more information about UCLan's research in this area go to

http://www.uclan.ac.uk/researchgroups/ and search for <name of research Group>.

For information about Research generally at UCLan please go to http://www.uclan.ac.uk/research/

All outputs in CLoK are protected by Intellectual Property Rights law, including Copyright law. Copyright, IPR and Moral Rights for the works on this site are retained by the individual authors and/or other copyright owners. Terms and conditions for use of this material are defined in the policies page.

\section{CLoK}

Central Lancashire online Knowledge www.clok.uclan.ac.uk

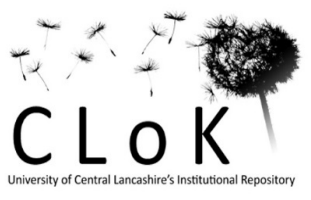


BRIEF REPORT: Evaluation of a cognitive skills programme for male prisoners - Exploring treatment effectiveness

Jane L. Ireland ${ }^{1 *}$, Jackie Bates-Gaston ${ }^{2}$, Kevin Markey $^{2}$, Leah Greenwood $^{1}$, Carol A Ireland ${ }^{1}$

${ }^{1}$ University of Central Lancashire, UK; Ashworth Research Centre, Mersey Care NHS Trust;

${ }^{2}$ The Northern Ireland Prison Service.

Note: The views expressed in this report are those of the authors and not the NI Prison Service.

*Corresponding author: JLIreland1@uclan.ac.uk 


\begin{abstract}
Aim: The current study provides an evaluation of a cognitive skills programme (Enhanced Thinking Skills) with adult prisoners.
\end{abstract}

Method: A pre and post treatment-only design with 171 male prisoners, using self-report psychometric measures.

Results: Significant differences were found in the direction expected. Clinical recovery using stringent methods was not indicated, although improvement/partial response was across a number of domains.

Originality: This study represents the first prison study to distinguish between levels of positive change. It questions previous interpretations of treatment outcome.

Implications for practice: Expectations for treatment outcome for short term interventions should be more realistic; Cognitive skills programmes may be best considered as precursors to longer term therapies; Treatment outcome should focus on improvement and not recovery. 
Cognitive skills group-based programmes, such as Enhanced Thinking Skills (ETS), Reasoning and Rehabilitation (R\&R), and the Thinking Skills Programme (TSP) have been widely implemented in prisons as a means of reducing re-offending and risk. All share the principles of Cognitive Behavioural Therapy (CBT) and focus on developing skills in perspective taking, self-control and problem-solving.

Two sets of outcome measures have generally been employed; reconviction and psychometric evaluation. Mixed results have been found. For example, a large scale evaluation for male prisoners demonstrated a 14 percent reduction in offending for mediumlow risk offenders and 11 percent for medium-high risk offenders at a two year follow up (Friendship et al, 2003). However, no differences were found between the treatment and control group in a follow up study (Falshaw, Friendship, Travers \& Nugent, 2004). Reconviction data does tend to be highly skewed and represent a measure of re-conviction but not offending (Serin et al, 2013). Its application as a measure of treatment impact has been questioned. Psychometric evaluation is an alternative to this and a standard element of treatment evaluation that captures changes in specific areas targeted by treatment (Gobbett \& Sellen, 2014). Positive changes have been reported; McDougall et al (2009) demonstrated treatment effects with a large matched control group using adult male prisoners where impulsivity reduced, offence-focused attitudes decreased, and more personal responsibility was indicated. Small scale studies not employing a control sample have also demonstrated positive change following treatment on similar areas (Gobbett \& Sellen, 2014).

Some evaluations have, however, employed incorrect methods of analysis (as noted by Serin et al, 2013), failing to report the significance of clinical change (e.g. Reliability Criterion) between pre and post time periods (Gobbett \& Sellen, 2014), or have adopted overly-stringent approaches to calculating clinical change that fail to account for the specifics of the sample. Indeed, there has been a focus on determining recovery on outcome measures as opposed to improvement (Wise, 2004), with the latter potentially a more realistic outcome for a short term intervention dealing with entrenched attitudes and behaviour.

The current study aims to add to the literature on the impact of cognitive skills programmes, namely ETS, by exploring changes following intervention completion. It will examine in more detail what can be considered improvement. Significant changes in outcome measures are predicted post treatment in the direction expected for positive change. 
Method

Sample: Three prison establishments from Northern Ireland were included, with a total of 171 adult male participants (Mean Age: 37.9, SD = 10.4]. Most were serving a sentence for more than one offence, with the most common being violence $(n=112)$, followed by burglary $(n=$ $64)$ and theft $(\mathrm{n}=55)$.

Design: All prisoners at the three establishments that had completed the intervention were included; there was no exclusion criteria applied. Measures were completed immediately prior to the intervention and repeated following completion. There was no comparison group; a pre-post-treatment-group only design was adopted.

Intervention being evaluated: Enhanced Thinking Skills (ETS) programme, a 20-session group-based therapy programme of around 40 hours of treatment contact time (Friendship et al, 2003).

Measures: The following measures were employed (see McDougall et al, 2009 and Gobbett $\&$ Sellen, 2014 for additional detail on each measure).

- Crime PICS II: 20 items considering attitudes towards offending, with an additional 15 items that capture problems prisoners expect to be presented with.

- Psychological Inventory of Criminal Thinking Styles (PICTS): 80 items relating to eight unhelpful thinking styles, i.e. mollification (justification); cut off (elimination of criminal deterrents); entitlement; power orientation (using aggression to control); sentimentality (self-centred approach to offence atonement); super optimism (failing to account for reality of negative consequences of offending); cognitive indolence (impulsive problem-solving); and discontinuity (inadequate self-discipline), with two validity scales (confusion and defensiveness).

- Social Problem Solving Questionnaire: ten scenarios to assess assertive, aggressive and passive problem solving, and the generation of solutions.

- Long Questionnaire: including the Eysenck Impulsivity Scale (24 items), Gough Socialisation Scale (45 items determining deviation from social norms), and Low Self-Esteem Scale (eight items).

- Locus of Control: 18 items with a high score equating to an internal locus of control and a low score to external locus of control. 


\section{Results}

Change was examined using the following:

- Assessment of significance of group differences pre and post scores using Wilcoxon to account for non-normality.

- Reliable Change criterion (RC) using pre group SD and published reliabilities of the outcome measures (McDougall et al, 2009). Confidence Level of 95\% was utilised (1.96) and SE of change calculated.

- Determination of a clinical cut off to indicate if post therapy scores moved into a 'recovery' [functional population] range, determined as $2 \mathrm{SD}$ or more from the pretherapy mean (Atkins, Bedics, McGlinchey \& Beauchaine, 2005). This method is used for the Jacobson-Truax approach to determine clinical significance ${ }^{1}$ whereas others argue that $1 \mathrm{SD}$ and $0.5 \mathrm{SD}$ cut-offs can also be used to indicate improvement/partial response and minimal positive response respectively (Wise, $\left.2004^{2}\right)$.

- Classification of participants using the stringent Jacobson-Truax method into 'recovered', 'improved', 'unchanged' and 'deteriorated'.

Results are presented in Table 1

\section{Discussion}

If group differences alone are considered, positive change was evidenced in cognition, problem solving, impulsivity and self-esteem. These results are similar to previous research (e.g. Gobbett \& Sellen, 2014; McDougall et al, 2009). There was also unexpected significant group differences, the most notable being that of victim hurt denial increasing. This is not a wholly unexpected finding, however, with previous studies noting difficulties with victim empathy (Gobbett \& Sellen, 2014; Serin et al, 2013).

However, the contribution of the current study is not focused on group comparison alone but also on individual change as well as the reliability and significance of this. Using the stringent Jacobson-Truax method there was no evidence for 'recovery' in the current sample, with notable figures only for 'improvement' in relation to specific cognition

\footnotetext{
${ }^{1}$ Also accounts for RC: for 'recovery' participants need to pass the cut-off (2 SD) and RC in the right direction. ${ }^{2}$ Further argues that improvement can be determined by considering either the RC or the cut-off and that a RC of 1.96 may be too conservative for some measures and one of .84 could be preferred in some instances.
} 
(anticipation of offending), problem-solving, locus of control and self-esteem. The JacobsonTruax method, although popular, uses measure reliability and cut-offs that do not account for the uniqueness of prison samples. We expect such samples to be skewed, to have marked variations in score spread (producing large SD), with difficulties in measurement reliability. Methods such as Reliable Change (RC) and Jacobson-Truax are developed more for populations that do not routinely suffer from this.

Being more flexible concerning treatment outcome can prove useful. Using a wider application of cut-offs that allowed for 2 SD ('recovery'), 1 SD ('improvement/partial response') and 0.5 SD ('minimal') in the positive direction, demonstrated that almost half the sample showed 'recovery' on SD cut-off alone in relation to the anticipation of re-offending, a fifth in relation to aggressive problem solving, and a third in relation to more appropriate socialisation. Improvement/partial response was also demonstrated regarding the majority of cognitive measures, for impulsivity and problem solving. This indicates there is something positive happening following this brief therapeutic intervention but how we define positive outcome should be reconsidered. Can it really be suggested that 'recovery' is achievable with an intervention of only 40 hours treatment contact time when focus is skills development and attitude/belief change? A more realistic expectation would be for 'improvement'. The current study provides evidence for this, even accounting for the method used. This suggests it would be unreasonable to argue that such intervention is not having a positive effect; rather it could suggest that the value of such an intervention may instead lie in facilitating the positive preparation of a prisoner for engagement in more intensive therapy; thus a precursor for more serious offenders.

The evaluation of treatment outcome is, nevertheless, only as good as the outcome measures used, with problems in this area well noted (e.g. Serin et al, 2013). The current study recognises this, plus the obvious limitation of not having a control group and the use of a single follow up point. Nevertheless, the sample was a good size and employed outcome measures tied into the learning aims of the intervention. Future research could build on the findings by addressing design limitations and extending outcome measures to include an assessment of skills and resources that allow prisoners to apply and internalize learning during intervention (Serin et al, 2013).

\section{References}

Atkins, D.C., Bedics, J. D., McGlinchey., J., Beauchaine, T. P. (2005). Assessing clinical significance: Does it matter which method we use: Brief report. Journal of Consulting and Clinical Psychology, 73(5), pp. 982 - 989. 
Falshaw, L., Friendship, C., Travers, R., Nugent, F. (2004). Searching for 'what works': HM Prison Service accredited cognitive skills programmes. The British Journal of Forensic Practice, 6 (2), pp. 3 - 13.

Friendship, C., Blud, L., Erikson, M., Travers, R., Thornton, D. (2003). Cognitivebehavioural treatment for imprisoned offenders: An evaluation of HM Prison Service's cognitive skills programmes. Legal and Criminological Psychology, 8. 103 -114 .

Gobbett. M. J., Sellen, J. L. (2014). An evaluation of the HM Prison Service 'Thinking Skills Programme' using psychometric assessments. International Journal of Offender Therapy and Comparative Criminology, 58(4), 454 - 473.

McDougall, C., Perry, A. E., Clarbour, J., Bowles, R.., Worthy, G. (2009). Evaluation of HM Prison Service enhanced thinking skills programme: Report on the outcomes of a randomised control trial. Ministry of Justice Research Series No 3/09. London, England: Ministry of Justice.

Serin, R.C., Lloyd, C. D., Helmus, L., Derkzen, D. M., Luong, D. (2013). Does intraindividual change predict offender recidivism? Searching for the Holy Grail in assessment offender change. Aggression and Violent Behaviour, 18, 32 - 53.

Wise, E. A. (2004). Methods for analysing psychotherapy outcomes: A review of clinical significance, Reliable Change, and recommendations for future directions. Journal of Personality Assessment, 82(1), pp. 50 - 59. 
Table 1. Outcome measures pre and post ETS programme

\begin{tabular}{|c|c|c|c|c|c|c|c|c|}
\hline Measure & & & & & & & Cut-off* & Jacobson-Truax method \\
\hline & & $\begin{array}{l}\text { Pre mean } \\
\text { (SD) } \\
\text { Post mean } \\
\text { (SD) }\end{array}$ & $\begin{array}{l}\text { Post-pre } \\
\text { difference } \\
\text { sig }\end{array}$ & $\begin{array}{l}\text { SE of } \\
\text { Change } \\
(\mathrm{RC})\end{array}$ & $\begin{array}{l}\text { Reliable } \\
\text { Improvement } \\
(\%) \mathrm{n}\end{array}$ & $\begin{array}{l}\text { Reliable } \\
\text { Deterioration } \\
(\%) \mathrm{n}\end{array}$ & $\begin{array}{l}(\%) \mathrm{n} \text { recovered } \\
(\%) \mathrm{n} \\
\text { improved/partial } \\
\text { response } \\
(\%) \mathrm{n} \text { minimal }\end{array}$ & $\begin{array}{l}(\%) \mathrm{n} \text { recovered } \\
(\%) \mathrm{n} \text { improved } \\
(\%) \mathrm{n} \text { unchanged } \\
(\%) \mathrm{n} \text { deteriorated }\end{array}$ \\
\hline \multirow{5}{*}{$\begin{array}{l}\text { Crime PICS- } \\
\text { II } \\
(\mathrm{n}=171: \\
\text { problem } \\
\text { inventory } \mathrm{n}= \\
166)\end{array}$} & $\begin{array}{l}\text { General attitude } \\
\text { to offending }\end{array}$ & $\begin{array}{l}36.6(10.7) \\
35.3(9.7)\end{array}$ & NS & $\begin{array}{l}7.43 \\
(14.6)\end{array}$ & $(9.3) 16$ & $(4.7) 8$ & $\begin{array}{l}(0) 0 \\
(19.3) 33 \\
(35) 60\end{array}$ & $\begin{array}{l}(0) 0 \\
(9.3) 16 \\
(86) 147 \\
(4.7) 8\end{array}$ \\
\hline & $\begin{array}{l}\text { Anticipation of } \\
\text { reoffending }\end{array}$ & $\begin{array}{l}11.3(3.9) \\
4.8(2.19)\end{array}$ & $\begin{array}{l}Z=10.8 ; p \\
<.001\end{array}$ & $\begin{array}{l}2.79 \\
(5.5)\end{array}$ & $(60.2) 103$ & (0) 0 & $\begin{array}{l}(45) 77 \\
(44) 75 \\
(7.0) 12\end{array}$ & $\begin{array}{l}\text { (0) } 0 \\
(60.2) 103 \\
(24) 41 \\
(0) 0\end{array}$ \\
\hline & $\begin{array}{l}\text { Victim hurt } \\
\text { denial }\end{array}$ & $\begin{array}{l}4.8(2.1) \\
11.4(3.8)\end{array}$ & $\begin{array}{l}\mathrm{Z}=11.1, \mathrm{p} \\
<.001\end{array}$ & $\begin{array}{l}1.54 \\
(3.0)\end{array}$ & (1.7) 3 & (75) 128 & $\begin{array}{l}\text { (0) } 0 \\
\text { (0) } 0 \\
\text { (0) } 0\end{array}$ & $\begin{array}{l}\text { (0) } 0 \\
(0) 0 \\
(25) 43 \\
(75) 128 \\
\end{array}$ \\
\hline & $\begin{array}{l}\text { Evaluation of } \\
\text { crime as } \\
\text { worthwhile }\end{array}$ & $\begin{array}{l}9.6(3.5) \\
9.1(3.5)\end{array}$ & $\begin{array}{l}Z=-2.16, p \\
<.03\end{array}$ & $\begin{array}{l}3.36 \\
(6.6)\end{array}$ & (5.3) 9 & (1.2) 2 & $\begin{array}{l}(0) 0 \\
(8.5) 5 \\
(1.2) 2\end{array}$ & $\begin{array}{l}(0) 0 \\
(5.3) 9 \\
(93.6) 160 \\
(1.2) 2\end{array}$ \\
\hline & $\begin{array}{l}\text { Problem } \\
\text { inventory }\end{array}$ & $\begin{array}{l}30.4(9.4) \\
25.7(8.3)\end{array}$ & $\begin{array}{l}Z=-6.07, p \\
<.001\end{array}$ & $\begin{array}{l}5.48 \\
(10.7)\end{array}$ & $(22.3) 37$ & (3.6) 6 & $\begin{array}{l}(0) 0 \\
(38.5) 64 \\
(26.5) 44\end{array}$ & $\begin{array}{l}(0) \\
(22.3) 37 \\
(74) 123 \\
(3.6) 6\end{array}$ \\
\hline $\begin{array}{l}\text { PICTS } \\
(\mathrm{n}=165)\end{array}$ & Mollification & $\begin{array}{l}12.8(4.0) \\
11.5(3.7) \\
\end{array}$ & $\begin{array}{l}Z=-5.04, p \\
<.001\end{array}$ & $\begin{array}{l}3.44 \\
(6.7) \\
\end{array}$ & (7.3) 12 & (1.2) 2 & $\begin{array}{l}(0) \\
(31.5) 52\end{array}$ & $\begin{array}{l}(0) \\
(7.3) 12\end{array}$ \\
\hline
\end{tabular}




\begin{tabular}{|c|c|c|c|c|c|c|c|}
\hline & & & & & & $(30.3) 50$ & $\begin{array}{l}(91.5) 151 \\
(1.2) 2\end{array}$ \\
\hline Cut Off & $\begin{array}{l}15.8(5.3) \\
13.9(5.0)\end{array}$ & $\begin{array}{l}\mathrm{Z}=-4.8, p \\
<.001\end{array}$ & $\begin{array}{l}3.53 \\
(6.9)\end{array}$ & $(15.1) 25$ & (1.8) 3 & $\begin{array}{l}(0) \\
(30.9) 51 \\
(26.7) 49\end{array}$ & $\begin{array}{l}(0) \\
(15.1) 25 \\
(83.0) 137 \\
(1.8) 3 \\
\end{array}$ \\
\hline Entitlement & $\begin{array}{l}11.5(3.6) \\
10.9(3.6)\end{array}$ & $\begin{array}{l}\mathrm{Z}=-2.58, p \\
<.01\end{array}$ & $\begin{array}{l}3.26 \\
(6.4)\end{array}$ & $(4.8) 8$ & $(3.0) 5$ & $\begin{array}{l}(0) 0 \\
(37) 61 \\
(26) 43\end{array}$ & $\begin{array}{l}(0) 0 \\
(4.8) 8 \\
(92.1) 152 \\
(3.0) 5\end{array}$ \\
\hline Power orientation & $\begin{array}{l}12.5(4.3) \\
11.3(3.8)\end{array}$ & $\begin{array}{l}\mathrm{Z}=-4.19, \mathrm{p} \\
<.001\end{array}$ & $\begin{array}{l}3.59 \\
(7.0)\end{array}$ & $(6.1) 10$ & (1.2) 2 & $\begin{array}{l}(0) 0 \\
(29.7) 49 \\
(24.2) 40\end{array}$ & $\begin{array}{l}(0) 0 \\
(6.1) 10 \\
(92.7) 153 \\
(1.2) 2\end{array}$ \\
\hline Sentimentality & $\begin{array}{l}15.7(3.6) \\
14.8(3.5)\end{array}$ & $\begin{array}{l}\mathrm{Z}=-3.30, p \\
<.001\end{array}$ & $\begin{array}{l}3.43 \\
(6.7)\end{array}$ & (4.2) 7 & (1.2) 2 & $\begin{array}{l}(1.8) 3 \\
(23.6) 39 \\
(30.9) 51\end{array}$ & $\begin{array}{l}(1.8) 3 \\
(4.2) 7 \\
(92.7) 153 \\
(1.2) 2\end{array}$ \\
\hline Super optimism & $\begin{array}{l}14.6(4.3) \\
13.9(4.2)\end{array}$ & $\begin{array}{l}Z=-3.06, p \\
<.002\end{array}$ & $\begin{array}{l}3.70 \\
(7.2)\end{array}$ & (2.4) 4 & (1.2) 2 & $\begin{array}{l}(0) 0 \\
(21.8) 36 \\
(30.9) 51\end{array}$ & $\begin{array}{l}(0) 0 \\
(2.4) 4 \\
(96.4) 159 \\
(1.2) 2\end{array}$ \\
\hline $\begin{array}{l}\text { Cognitive } \\
\text { indolence }\end{array}$ & $\begin{array}{l}17.2(4.9) \\
15.1(4.7)\end{array}$ & $\begin{array}{l}\mathrm{Z}=5.28, p \\
<.001\end{array}$ & $\begin{array}{l}3.46 \\
(6.8)\end{array}$ & (13.9) 23 & (0.6) 1 & $\begin{array}{l}(0.6) 1 \\
(33.9) 56 \\
(15.1) 25\end{array}$ & $\begin{array}{l}(0) 0 \\
(13.9) 23 \\
(85.4) 141 \\
(0.6) 1\end{array}$ \\
\hline Discontinuity & $\begin{array}{l}16.2(5.0) \\
14.8(4.8)\end{array}$ & $\begin{array}{l}Z=-4.03, p \\
<.001\end{array}$ & $\begin{array}{l}3.27 \\
(6.4)\end{array}$ & (11.5) 19 & (1.8) 3 & $\begin{array}{l}(0) 0 \\
(30.3) 50 \\
(25.4) 42\end{array}$ & $\begin{array}{l}(0) 0 \\
(11.5) 19 \\
(86.7) 143 \\
(1.8) 3\end{array}$ \\
\hline
\end{tabular}




\begin{tabular}{|c|c|c|c|c|c|c|c|c|}
\hline $\begin{array}{l}\text { Problem } \\
\text { Solving } \\
(\mathrm{n}=100)\end{array}$ & Assertiveness & $\begin{array}{l}19.4(3.7) \\
20.1(4.4)\end{array}$ & $\begin{array}{l}\mathrm{Z}=-3.25, p \\
<.001\end{array}$ & $\begin{array}{l}3.60 \\
(7.0)\end{array}$ & (8) 8 & (2) 2 & $\begin{array}{l}(0) 0 \\
(30) 30 \\
\text { (14) } 14\end{array}$ & $\begin{array}{l}\text { (0) } 0 \\
(8) 8 \\
(90) 90 \\
(2) 2 \\
\end{array}$ \\
\hline & Aggressive & $\begin{array}{l}4.8(5.7) \\
3.8(3.2)\end{array}$ & $\begin{array}{l}\mathrm{Z}=2.51, \mathrm{p} \\
<.01\end{array}$ & $\begin{array}{l}3.24 \\
(6.3)\end{array}$ & (10) 10 & (2) 2 & $\begin{array}{l}(19) 19 \\
\text { (11) } 11 \\
\text { (12) } 12\end{array}$ & $\begin{array}{l}\text { (1) } 1 \\
\text { (10) } 10 \\
\text { (87) } 87 \\
\text { (2) } 2 \\
\end{array}$ \\
\hline & Passive & $\begin{array}{l}20.6(5.8) \\
19.9(6.1)\end{array}$ & NS & $\begin{array}{l}3.85 \\
(7.5)\end{array}$ & (11) 11 & (7) 7 & $\begin{array}{l}\text { (8) } 8 \\
\text { (10) } 10 \\
\text { (13) } 13\end{array}$ & $\begin{array}{l}\text { (1) } 1 \\
\text { (11) } 11 \\
\text { (81) } 81 \\
\text { (7) } 7 \\
\end{array}$ \\
\hline $\begin{array}{l}\text { Locus of } \\
\text { Control } \\
(n=168)\end{array}$ & & $\begin{array}{l}44.7(7.2) \\
49.6(7.7)\end{array}$ & $\begin{array}{l}\mathrm{Z}=-7.42, p \\
<.001\end{array}$ & $\begin{array}{l}4.88 \\
(9.6)\end{array}$ & $(22.6) 38$ & (2.9) 5 & $\begin{array}{l}(12.5) 21 \\
(28) 47 \\
(23.2) 39\end{array}$ & $\begin{array}{l}(6.5) 11 \\
(22.6) 38 \\
(67.8) 114 \\
(2.9) 5\end{array}$ \\
\hline $\begin{array}{l}\text { Long } \\
\text { Questionnaire }\end{array}$ & $\begin{array}{l}\text { Impulsivity } \\
(\mathrm{n}=141)\end{array}$ & $\begin{array}{l}11.3(5.7) \\
8.4(5.8)\end{array}$ & $\begin{array}{l}\mathrm{Z}=6.59, \mathrm{p} \\
<.001\end{array}$ & $\begin{array}{l}4.43 \\
(8.7)\end{array}$ & (11.3) 16 & (1.4) 2 & $\begin{array}{l}(5.0) 7 \\
(48.9) 69 \\
(26.9) 38\end{array}$ & $\begin{array}{l}(0.7) 1 \\
(11.3) 16 \\
(86.5) 122 \\
(1.4) 2\end{array}$ \\
\hline & $\begin{array}{l}\text { Socialisation } \\
(\mathrm{n}=105)\end{array}$ & $\begin{array}{l}18.9(5.8) \\
21.8(6.3)\end{array}$ & $\begin{array}{l}\mathrm{Z}=-4.68, p \\
<.001\end{array}$ & $\begin{array}{l}2.74 \\
(5.4)\end{array}$ & $(4.8) 5$ & (22.8) 24 & $\begin{array}{l}(30.5) 32 \\
(4.8) 5 \\
(16.2) 17\end{array}$ & $\begin{array}{l}(0.7) 1 \\
(4.8) 5 \\
(71.4) 75 \\
(22.8) 24\end{array}$ \\
\hline & $\begin{array}{l}\text { Low self esteem } \\
(\mathrm{n}=90)\end{array}$ & $\begin{array}{l}3.69(2.5) \\
2.3(2.5)\end{array}$ & $\begin{array}{l}\mathrm{Z}=-4.88, p \\
<.001\end{array}$ & $\begin{array}{l}1.36 \\
(2.7)\end{array}$ & $(27.7) 25$ & (3.3) 3 & $\begin{array}{l}(11.1) 10 \\
(1.1) 1 \\
(1.1) 1\end{array}$ & $\begin{array}{l}(1.1) 1 \\
(27.7) 25 \\
(67.8) 61 \\
(3.3) 3\end{array}$ \\
\hline
\end{tabular}

$\mathrm{RC}=$ Reliable Change Criterion; NS = Not significant; * SD positive cut-off; 'Recovered' = 2 SD from pre-mean; 'Improved/partial response' = $1 \mathrm{SD}$ from pre-mean; Minimal $=0.5 \mathrm{SD}$ 